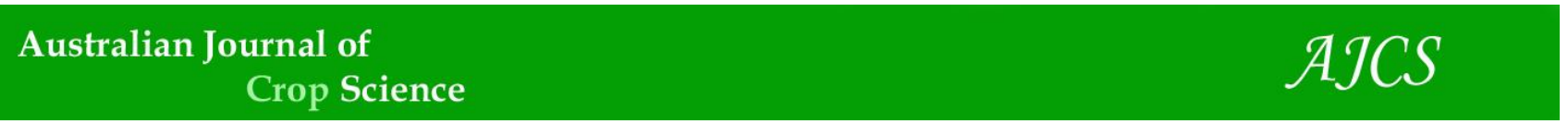

AJCS 15(03):377-386 (2021)

ISSN:1835-2707

doi: 10.21475/ajcs.21.15.03.p2751

\title{
Cultivation of ruziziensis grass (Urochloa ruziziensis) using swine liquid manure fertilization
}

\author{
Marinho Rocho da Silva ${ }^{1}$, Joadil Gonçalves Abreu ${ }^{1}$, Oscarlina Lucia dos Santos Weber ${ }^{1}$, Livia Vieira de \\ Barros ${ }^{1}$, Edna Maria Bonfim-Silva ${ }^{2}$, Ana Paula Alves Barreto Damasceno ${ }^{2}$, Wlly Cristiny Mendes de \\ Oliveira $^{1}$
}

${ }^{1}$ Federal University of Mato Grosso - UFMT, Faculty of Agronomy and Zootechny, 2367 Fernando Corrêa da Costa Avenue, Cuiabá, 78060-900, Brazil

${ }^{2}$ Federal University of Rondonópolis - UFR, Institute of Agricultural and Technological Sciences, 5055 Students Avenue Rondonópolis, 78.735-901, Brazil

\begin{abstract}
The objective of this study was to evaluate the use of liquid swine manure (LSM) as fertilization in the implantation of Urochloa ruziziensis. The experimental design was randomized blocks with five treatments and four replications, with the treatments being four doses of $\operatorname{LSM}\left(0 ; 100 ; 200\right.$ and $\left.300 \mathrm{~m}^{3} \mathrm{ha}^{-1}\right)$ and one dose of mineral fertilization. Seven cuts were carried out uniformly, after which plant height (PH), total dry mass yield (TDMY), crude protein content (CP), neutral detergent fiber (NDF) and acid detergent

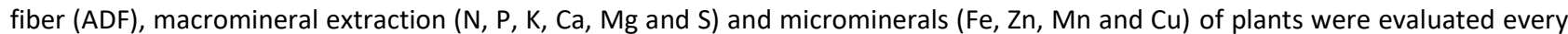
30 days. Mineral fertilization provided higher $\mathrm{PH}, \mathrm{CP}$ content and extraction of $\mathrm{N}$ and $\mathrm{S}$, but lower NDF content. For ADF variable, there was no difference between treatments. The results of dry mass yield (DMY) and extractions of $\mathrm{P}, \mathrm{K}, \mathrm{Ca}$ and $\mathrm{Mn}$ showed that the effect of $300 \mathrm{~m}^{3} \mathrm{ha}^{-1}$ LSM was statistically equal to mineral fertilization. For extractions of $\mathrm{Mg}, \mathrm{Fe}, \mathrm{Zn}$ and Cu doses of 200 and $300 \mathrm{~m}^{3} \mathrm{ha}^{-1}$ did not differ statistically from mineral fertilization. Among the doses of LSM, there was increasing linear effect, with increases in the variables DMY (30.89\%), PH (14.94\%), CP (17\%), N (53.01\%), P (40.79\%), K (27.84\%), Ca (35.17\%), Mg (29.6\%), S (47.13\%), Fe (31.2\%), $\mathrm{Zn}(31.6 \%)$ and $\mathrm{Mn}(23.04 \%)$. For Cu extraction, there was a quadratic effect with the highest extraction in the dose of $26.36 \mathrm{~m}^{3}$, obtaining an increase of $19.94 \%$ in relation to treatment without application. It is important to study different LSM dosages to avoid risk of heavy metal toxicity. The LSM is an alternative in place of mineral fertilization for Urochloa ruziziensis grass.
\end{abstract}

Keywords: crude protein content, neutral detergent fiber, acid detergent fiber, mineral nutrition of plants, pasture quality, tropical forages, wastewater.

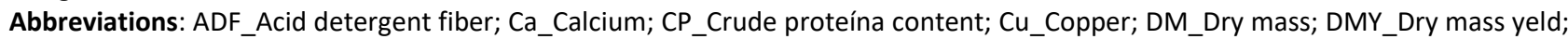
Fe_Iron; K_Potassium; LSM_Liquid swine manure; Mn_Manganese; Mg_Magnesium; N_Nitrogen; NDF_Neutral detergent fiber; P_Phosphorus; PH_Plant height; S_Sulfur; TDMY_Total dry mass yeld; Zn_Zinc.

\section{Introduction}

In recent years, Brazilian swine farming has highlighted worldwide and is currently the fourth largest swine producer and exporter in the world. An increase of $5.6 \%$ is estimated in swine meat production in Brazil compared to 2018 along with an increase in exports around $23.3 \%$ (CONAB, 2019). However, this activity is considered potentially polluting, as it uses abundant water in its production process, reflecting the excessive production of leachate (Sousa et al., 2014; Yuan et al., 2018). This huge slurry volume passes through a biodigester, where the gaseous part is destined for energy production and the liquid part is stored in ponds or tanks to later be applied in pastures or crops as fertilizer.

Wastewater from swine waste may represent an important fertilizer or a potential environmental risk, depending on how the resource is managed (Egewarth et al., 2015; Boitt et al., 2018). There is a risk in using swine waste as pollutant to soil and groundwater, if the soil adsorption capacity and crop need is not considered (Lourenzi et al., 2013; Orrico Junior et al., 2013).
The risk in the application of swine liquid manure can be reduced when the technical criteria of recommendation for its application in the soil are obeyed. Therefore, it is necessary to know the manure composition to calculate the volume that should be applied to the culture system (Lavoisier, 1789; Moraes et al., 2017)

A well-planned fertilization with swine liquid manure can bring benefits (Erthal et al., 2010; Matos et al., 2017), increasing the availability of macro and micronutrients in the soil (Angers et al., 2010; Matos et al., 2017; Tavanti et al., 2017). This increases the absorption of water and nutrients by plants (Galbiatti et al., 2011; Gomes et al., 2017) and amount and biodiversity of the soil fauna community (Silva et al., 2014). Long-term, swine wastewater increases microbial activity and soil organic matter (Morales et al., 2015).

Pasture production is limited when $\mathrm{N}, \mathrm{P}$ and $\mathrm{K}$ are not adequate. These nutrients are among the main constituents of swine wastewater, therefore, their use can contribute to 
animal production in pasture, increasing the supply of forage in quantity and quality for animals (Serpa Filho et al., 2013; Pandolfo and Veiga, 2016; Boitt et al., 2018).

In time of fodder scarcity alternatives are sought to mitigate the impact on zoological indices of grazing animals by integrated system. One of the forage used in this system is ruziziensis grass (Urochloa ruziziensis) due to the large emergence capacity of its seeds in over-sowing, excellent soil cover and easy management and late flowering, which favors grazing time (Aukar, 2011). It can be used by animals during the off-season of soybean crop, contributing to improve performance in this period, without compromising the production of subsequent crop. One of the disadvantages could be the susceptiblity to pasture leafhopper.

In view of the above, the objective of this study was to evaluate the productivity, nutritional value and mineral extraction of Urochloa ruziziensis in the first year of implantation in response to fertilization with liquid swine manure.

\section{Results and discussion}

For the variables plant height $(\mathrm{PH})$ and crude protein $(\mathrm{CP})$, the highest values were observed for the application of mineral fertilization. Regarding the variable neutral detergent fiber (NDF), we observed that the lowest value was for the application of mineral fertilization. For the variable acid detergent fiber (ADF) there was no significant difference between the values observed for the doses of LSM and mineral fertilization. Total dry mass yield (TDMY) for the dose of $300 \mathrm{~m}^{3} \mathrm{ha}^{-1}$ was statistically equal to mineral (Table 1).

\section{Production characteristics of Urochloa ruzizienseis grass as a function of the treatments applied}

Mineral fertilization increased plant height $(\mathrm{PH})$ about $9.27 \%$, compared to the higher doses of LSM. In all treatments, $\mathrm{PH}$ was above $30 \mathrm{~cm}$ before grazing, recommended by Guedes (2012). The ruziziensis grass tends to increase TDMY, when managed in PHs above $40 \mathrm{~cm}$. This fact was proven in all treatments, especially in the highest dose of LSM and mineral fertilization that were equal.

Seidel et al. (2010) analyzed how the application of swine manure influences the corn crop in no-tillage system and and saw that treatments with manure did not differ from treatments that received mineral fertilization. Silva et al. (2015) compared the influence of mineral fertilization and swine manure on the bromatological characteristics of Brachiaria decumbens at different cutting heights. These authors reported a greater mineralization of organic matter present in swine manure, optimizing its potential as organic fertilizer and ensuring production of dry matter equivalent to plants with mineral fertilization.

Supporting our results, Penn et al. (2013) studied the effect of swine manure sludge on forage growth and observed that there was an increase in biomass production and plant height, compared to chemical fertilization.

Application of LSM doses in part or total showed significant differences on $\mathrm{PH}$ and TDMY with increasing linear adjustment (Figure 1).

There was an increase of $14.94 \%$ in $\mathrm{PH}$ when compared to the highest dose of LSM applied, compared to no-LSM treatment. This increase is related to the higher availability of $\mathrm{N}$ in the highest doses, as it promotes an increase in the growth of the aerial part of the plant (Castro et al., 2016).

The nutrients provided through LSM stimulated the growth of the forage plant (Serafim and Galbiatti, 2012). Research on forage plants confirms that the application of swine effluents promotes the increase in plant growth due to the nitrogen supply in the manure (Brustolin-Golin et al., 2016; Pandolfo and Veiga, 2016; Galindo et al., 2018).

Plant height is a characteristic that has a direct relationship with the morphological and physiological aspects of the plant, structural components and the quantity and quality of the forage produced (Fagundes, 2012).

The plant height has a positive correlation with TDMY, justifying the $30.89 \%$ increase in TDMY for the higher volume of LSM applied, compared to the dose without application of LSM. According to Aukar (2011) Urochloa ruziziensis produces 14 to $15 \mathrm{t} \mathrm{ha}^{-1}$ year of dry mass. However, in this study the dry mass values were higher in all treatments.

The use of LSM provided an increase in TDMY and the nutritional value of forage. These responses were also observed by Costa et al. (2009) and Quaresma et al. (2011) on Marandu and Tifton 85 (Urochloa brizantha cv. marandu and Cynodon spp cv. Tifton 85) weeds, respectively, evidencing the potential use of LSM as an alternative for fertilization in forage plants.

The increasing linear effect in TDMY was also found by Barnabas et al. (2007) with fertilization of 0; 50; 100 and 150 $\mathrm{m}^{3} \mathrm{ha}^{-1}$ of wastewater in Marandu grass (Urochloa brizantha cv. marandu). Orrico Junior et al. (2012), studied the effect of four doses of swine effluents $\left(0 ; 100 ; 200\right.$ and $300 \mathrm{~kg} \mathrm{ha}^{-1}$ equivalent $\mathrm{N}$ ) on dry mass production of piatã grass (Urochloa brizantha cv. piatã).

According to Pariz et al. (2010) Urochloa ruziziensis plants showed TDMY of 1,100 to $7,193 \mathrm{~kg} \mathrm{ha}^{-1}$ of dry matter, depending on the planting system and soil fertility conditions.

Serafim (2010), evaluated swine farming wastewater in Marandu grass pasture and found that the application of 600 $\mathrm{m}^{3}$ provided an accumulated dry mass yield of $22,779 \mathrm{~kg} D M$ $\mathrm{ha}^{-1}$ year. This is a value below those found in this study with 23,$404 ; 25,426$ and 27,448 of accumulated dry mass yield in doses 100; 200 and $300 \mathrm{~m}^{3} \mathrm{ha}^{-1}$ year of LSM (sum of the 10 applications), respectively.

Silva et al. (2019) studied three cultivars of Urochloa brizantha to identify which cultivar is most sensitive to fertilization with wastewater of swine, using doses ranging from 0.0 to $14.0 \mathrm{~g} \mathrm{dm}^{3} \mathrm{pot}^{-1}$. They found that regardless of the cultivar the increase in doses promoted the increase in plant height, which was occurred in the present study.

Fertilization with nitrogen sources accelerated growth (Galindo et al., 2018) and influenced the plant height. They reported that greater availability precludes plant's absorption, which was not achieved in this study.

\section{Nutritive value of Urochloa ruzizienseis grass as a function of the treatments}

The CP content was increased with the increase in LSM doses. However with the exception of mineral fertilization $(8.96 \%)$, the contents in the different LSM doses were below $7 \%$ which is the minimum percentage necessary for adequate nutrition of ruminants, according to Van Soest (1994). According to Montanari et al. (2013) leaf anatomy and high proportion of stem to leaves and low protein level 
is observed in tropical grasses due to their photosynthetic cycle of $\mathrm{C} 4$.

In mineral fertilization, there was an increase of $37.84 \%$ in the CP content over the $300 \mathrm{~m}^{3} \mathrm{ha}^{-1}$ LSM dose. The lowest $\mathrm{CP}$ content in the LSM doses may be related to variations in nutrient concentration due to the storage of liquid residue. However, we verified that the increase in doses raises nitrogen level and consequently the crude protein values.

Bernardi et al. (2018) analyzed the response of forage grasses of the Brachiaria, Cynodon and Panicum genus to nitrogen fertilization, in terms of dry matter production, crude protein and efficiency of nitrogen use. They concluded that nitrogen fertilization influences the production of dry matter and crude protein with consistent increases, with a more pronounced effect in relation to crude protein production.

The LSM doses increased the CP content linearly. The highest LSM dose provided an increase in CP content of $17.06 \%$ over the LSM dose without application (Figure 2).

Although it has a linear effect, the CP content at the highest LSM dose was $6.50 \%$, considered below the minimum appropriate for ruminant's nutrition. The $\mathrm{N}$ variation in the LSM is among the important causes for the lowest CP levels throughout the experiment.

Complementation can be performed, when the CP content in the forage is less than 7, according to Van Soest (1994). However, protein is a high-cost item in the formulation of supplements for cattle (Silva et al., 2015). Orrico Junior et al. (2013) observed a $19.84 \%$ increase in CP content in Piatã grass under irrigation when swine wastewater doses of 300 $\mathrm{m}^{3} \mathrm{ha}^{-1}$ were applied. Gomes et al. (2014) found that irrigation positively influenced the $\mathrm{CP}$ content in Piatã grass upon application of swine effluents doses.

Homem et al. (2016) evaluated the production of forage and root accumulation in Brachiaria decumbens cv. Basilisk with the use of swine wastewater as fertilizer, with doses ranging from 0 to $675 \mathrm{~mL} \mathrm{pot}^{-1}$. They found that the crude protein content was increased linearly with the increase in doses. A similar trend was observed in this work in relation to the doses used.

In mineral fertilization, there was a $4.83 \%$ reduction in the NDF content compared to the LSM dose of $300 \mathrm{~m}^{3} \mathrm{ha}^{-1}$. There were no differences in ADF contents between LSM doses and mineral fertilization. A similar result was obtained in an experiment with LSM doses and mineral fertilization in carpet grass pasture (Axonopus sp.) (Kottwitz, 2012).

There was no difference in NDF and ADF upon only the LSM doses. The mean NDF content was $61.07 \%$, below the values observed by Benett et al. (2008), which evaluated doses of 0 ; 50; 100; 150 and $200 \mathrm{~kg} \mathrm{ha}^{-1}$ of $\mathrm{N}$ in marandu grass (Urochloa brizantha cv. marandu) (cutting interval of 30 days), which found variations from 64.65 to $69.70 \%$. The value observed in the present study guarantees better use of nutrients by ruminal microorganisms in the diet and consequently better animal performance, because the improvement of the nutritional value of fodder is related to low levels of NDF $(<65 \%)$, and higher ability of animals to intake (Van Soest, 1994).

The ADF content is related to the digestibility of dry mass and reflects the concentration of lignin in the cell wall that limits the degradation of structural carbohydrates in the rumen. The average ADF content was $31.94 \%$. This content is close to those observed in a greenhouse by Silva et al. (2019) who found 34.41 to $36.30 \%$; 33.31 to $35.25 \%$; for piatã and marandu weeds fertilized with swine wastewater, respectively. Orrico Junior et al. (2013) found ADF variation from $31.96 \%$ to $36.76 \%$ in increasing doses of $N(0 ; 100 ; 200$ and $300 \mathrm{~kg} \mathrm{ha}^{-1}$ ) in Piatã grass.

The higher ADF levels cause longer digestion and the less consuming of fodder by animal. According to Nussio et al. (1998), fodder with ADF levels of $40 \%$, or more, have low consumption and lower digestibility.

\section{Nutrient extraction by Urochloa ruzizienseis grass as a function of the treatments applied}

There was greater extraction of $\mathrm{N}$ and $\mathrm{S}$ in mineral fertilization. The $300 \mathrm{~m}^{3} \mathrm{ha}^{-1}$ LSM and mineral fertilization were statistically equal on average dry matter yield (DMY) and for the extractions of $\mathrm{P}, \mathrm{K}, \mathrm{Ca}$ and $\mathrm{Mn}$. In the extractions of $\mathrm{Mg}, \mathrm{Fe}, \mathrm{Zn}$ and $\mathrm{Cu}$, doses 200 and $300 \mathrm{~m}^{3} \mathrm{ha}^{-1}$ did not differ statistically from mineral fertilization (Table 2).

Mineral nitrogen and sulfur were 56.34 and $37.36 \%$ higher in mineral fertilization at the highest dose of $300 \mathrm{~m}^{3} \mathrm{ha}^{-1}$ of LSM.

Based on the results we found that the dose of $300 \mathrm{~m}^{3} \mathrm{ha}^{-1}$ LSM can be considered as an alternative dose for fertilization of Urochloa ruziziensis in place of mineral fertilization.

In a study developed by Menezes et al. (2018) on maize nutrients extraction and export, fertilized with swine manure, the extraction of NPK nutrients followed a decreasing order in the vegetative period $\mathrm{K}>\mathrm{N}>\mathrm{P}$ and in the reproductive period $\mathrm{N}>\mathrm{K}>\mathrm{P}$ presenting a total accumulation in the aerial part of $179.2,70.97$ and $86.60 \mathrm{~kg} \mathrm{ha}^{-1}$ of NPK, respectively.

Eguchi et al. (2017) evaluated the minerals present and extracted from the mass of Marandu grass fertilized with chicken manure and managed without and with soil scarification. They found that for the nutrients analyzed $(\mathrm{N}$, $\mathrm{P}, \mathrm{K}, \mathrm{Mg}, \mathrm{Ca}, \mathrm{Cu}, \mathrm{Zn}$ ) mineral fertilization can be replaced by manure. The increase in the dose of chicken manure, consequently causes an increase in the extraction of $\mathrm{K}, \mathrm{Ca}$, $\mathrm{Mg}, \mathrm{P}, \mathrm{Zn}$ and $\mathrm{Cu}$ in marandu grass forage mass production. Comparing the LSM doses, a growing linear effect was observed for $\mathrm{N}$ and $\mathrm{P}$ levels. The application of LSM provided higher nitrogen and phosphorus extraction, with an increase of 53.01 and $40.79 \%$, respectively, compared to treatment without LSM application (Figure 3).

The highest mean concentration of $\mathrm{N}$ was found for the highest dose of LSM with $\mathrm{N}$ extraction of $41.36 \mathrm{~kg} \mathrm{ha}^{-1}$ per cut. This value is higher than the value found by Mendonça et al. (2014), which evaluated the extraction of macronutrients in Urochloa ruziziensis in a consortium with maize and found $\mathrm{N}$ concentration of $34.5 \mathrm{~kg} \mathrm{ha}^{-1}$. However, the highest extraction of $\mathrm{N}$ was diluted in the largest $\mathrm{DM}$ in the present study where $10.55 \mathrm{~kg}$ of $\mathrm{N}$ per tonne produced in the highest dose of LSM.

Regarding $\mathrm{P}$, the appropriate levels according to Raij et al (1996) are 0.8 to $3 \mathrm{~g} \mathrm{~kg}^{-1}$ in DM. In the present study, even in treatment without the application of LSM, the contents ranged from 12.03 to $12.91 \mathrm{~g} \mathrm{~kg}^{-1}$ in the DM. This high concentration of $\mathrm{P}$ in forage in all treatments is probably due to the residual effect on the soil left by the crop before implantation of the experiment.

The experimental area had been cultivated with soybean, which had to be desiccated. The soybean has a low $\mathrm{C} / \mathrm{N}$ ratio (Silva et al. 2006), which favors its decomposition and mineralization, contributing to the phosphorus available in the soil, since $77 \%$ of $\mathrm{P}$ can be recycled from the cultural remains and used by plants (Jones and Woodmanse, 1979). 
Maggi et al. (2011) quantified the nutrient leaching in the cultivated soil fertilized with swine liquid manure. They reported that high extraction of soil $P$ with small losses occurs when $P$ is supplied through the application of swine wastewater and not by mineral fertilization.

Phosphorus extraction was $51 \mathrm{~kg} \mathrm{ha}^{-1}$ upon application of 30 $\mathrm{m}^{3} \mathrm{ha}^{-1}$ LSM. This is different from the content observed by Mendonça et al. (2014) evaluating this same cultivar, whereas they found phosphorus extraction of $5.1 \mathrm{~kg} \mathrm{ha}^{-1}$ in DM. Thus, the Urochloa ruziziensis grass was shown to be good $\mathrm{P}$ extractor, because phosphorus and calcium are the elements that most limit the growth of forage, and it is necessary to supply through mineral supplementation to meet the needs of grazing animals.

There was an increasing linear effect of the LSM doses on the extraction of potassium and sulfur (Figure 4).

Potassium extraction was $27.84 \%$ higher at the dose $30 \mathrm{~m}^{3}$ $\mathrm{ha}^{-1}$ LSM, compared to treatment without application. However, when considering the appropriate levels proposed by Raij et al. (1996) from 12 to $30 \mathrm{~g} \mathrm{~kg}^{-1}$, the values in all experiments were below, ranging from 7.32 to $7.71 \mathrm{~g} \mathrm{~kg}^{-1}$. This occurred due to the management in the highest $\mathrm{PH}$ and higher DMY, which were favored by the $\mathrm{P}$ and $\mathrm{N}$ availability present in the soil.

Cassol et al. (2012) studied the availability of macronutrients and maize yield in oxisol fertilized with liquid swine manure, in which doses. The potassium content in the soil increased in fertilized treatments. According to the authors, the highest accumulation occurs in the highest doses and in the first $5 \mathrm{~cm}$ of the soil.

There was probably potassium recycling of the previous crop remnants, because the concentrations extracted from 25.05; 27.18 and $29.30 \mathrm{~kg} \mathrm{ha}^{-1}$ were higher than the applied amount 13.6; 18.7 and $24 \mathrm{~kg}^{-1}$ by fertilization in the doses of LSM of $10 ; 20$ and $30 \mathrm{~m}^{3} \mathrm{ha}^{-1}$, respectively.

Mean $\mathrm{S}$ concentration was increased by $47.13 \%$ with dose application of $30 \mathrm{~m}^{3} \mathrm{ha}^{-1}$ of LSM, compared to control treatment. The mean cut contents extracted by the plant were in the increasing order of 77.6; 89.8; 102.09 and $114.31 \mathrm{~kg} \mathrm{ha}^{-1}$ per dose, which means a variation of 25.04 to $29.11 \mathrm{~g} \mathrm{~kg}^{-1}$ in DM, values well above the concentration considered appropriate ( 0.8 to $2.5 \mathrm{~g} \mathrm{~kg}^{-1}$ of S) by Raij et al. (1996).

Although a sulphur supply has entered via LSM fertilization of $35.4 ; 70.8$ and $106.2 \mathrm{~kg} \mathrm{ha}^{-1}$ per application, the largest extraction probably came from the soil organic matter mineralization experiment (Table 3), since $S$ is considered a structural nutrient of organic matter (Lawlor et al., 2001).

For calcium and magnesium extraction, there was increasing linear effect as a function of the LSM doses (Figure 5).

The highest LSM dose increased about $35.17 \%$ of $\mathrm{Ca}$ extraction, compared to the dose without the application of LSM, while the extraction at the highest dose was $113.84 \mathrm{~kg}$ $\mathrm{ha}^{-1}$. Mendonça et al. (2014) verified Ca extraction of $10.8 \mathrm{~kg}$ $\mathrm{ha}^{-1}$ for Urochloa ruziziensis grass. Raij et al. (1996) evaluated the calcium levels in forage. The variation was from 27.33 to $29.11 \mathrm{~g} \mathrm{~kg}^{-1}$ in DM, exceeding the values of 3 to $6 \mathrm{~g} \mathrm{~kg}^{-1}$ in the DM considered as adequate.

This is due to the available calcium already present in the soil, as well as to the input, via LSM being higher than that extracted by the plant in the highest LSM doses. From a nutritional point of view, grasses are deficient in calcium, and there is a need for complementation via mineral supplementation to meet the needs of grazing animals.
However, using LSM may be an alternative to mitigate these deficiencies.

The use of LSM at the highest dose provided an increase of $29.60 \% \mathrm{Mg}$ in relation to the dose without the application of LSM. In all treatments, the levels ranged from 2.19 to $2.29 \mathrm{~g}$ $\mathrm{kg}^{-1}$ within the range of 1 to $4 \mathrm{~g} \mathrm{~kg}^{-1}$ in the DM, considered as adequate (Raij et al., 1996). The mean extraction per cut in the highest dose of LSM was $8.93 \mathrm{~kg} \mathrm{ha}^{-1}$ DM of magnesium, higher than the value obtained by Mendonça et al. (2014), while evaluated mineral extraction in Urochloa ruziziensis in consorsium with maize and obtained $\mathrm{Mg}$ extraction of $7.4 \mathrm{~kg}$ $\mathrm{ha}^{-1}$ in the DM.

There was a linear increasing effect of the LSM doses on iron and manganese extraction (Figure 6).

At $30 \mathrm{~m}^{3} \mathrm{ha}^{-1}$ of LSM, there was an increase of $31.2 \%$ of extracted iron, with $1169.3 \mathrm{~g} \mathrm{~kg} \mathrm{ha}^{-1}$, but below the values of 2002 to $3217 \mathrm{~g} \mathrm{~kg} \mathrm{ha}^{-1}$ obtained by Lima et al. (2016) in Brachiaria hibrida. In plants, the iron contents is ranged from 285.79 to $299 \mathrm{mg} \mathrm{kg}^{-1}$ in the DM, which is appropriate according to Carvalho et al. (2003), who found foliar Fe contents on average 100 to $487 \mathrm{mg} \mathrm{kg}^{-1}$ in Brachiaria.

In the extraction of manganese there was an increase of $23.04 \%$ in the highest LSM dose in relation to the dose without application. The mean extraction per cut was 210.38 $\mathrm{g} \mathrm{kg} \mathrm{ha}^{-1}$ at the highest dose. The values close to that were reported by Lima et al. (2016) in Brachachia hibrida, where iron extraction ranged from 805.3 to $1174.6 \mathrm{~g} \mathrm{~kg} \mathrm{ha}^{-1}$. In plant, the levels ranged from 52.15 to $56.2 \mathrm{mg} \mathrm{kg}^{-1}$ of DM, are considered low. Raij et al., (1996) recommended that adequate concentrations should be 50 to $250 \mathrm{mg} \mathrm{kg}^{-1}$. In this study, the values found for manganese were close to the bottom limit.

For extraction of $\mathrm{Zn}$ and $\mathrm{Cu}$, there was an increasing linear effect for zinc and quadratic effect for copper (Figure 7).

The highest LSM dose provided an increase in $\mathrm{Zn}$ extraction of $31 \%$, compared to control treatment. The mean extraction of $\mathrm{Zn}$ in the highest dose of LSM was $128.11 \mathrm{~g} \mathrm{~kg}$ $\mathrm{ha}^{-1}$. It is below the values found by Lima et al. (2016) who studied biofertilizers and fertilizers in Brachiaria hibrida and found $\mathrm{Zn}$ conceptions ranging from 161.1 to $240.1 \mathrm{~g} \mathrm{~kg} \mathrm{ha}^{-1}$ while the values ranged from 31.2 to $33.23 \mathrm{mg} \mathrm{kg}^{-1}$ in the DM. In all treatments, the concentrations are in the appropriate interval according to Perondi et al. (2007) which is 20 to $50 \mathrm{mg} \mathrm{kg}^{-1}$.

The highest mean extraction of $\mathrm{Cu}\left(64.75 \mathrm{~g} \mathrm{~kg} \mathrm{ha}^{-1}\right)$ was occurred at $26.36 \mathrm{~m}^{3} \mathrm{ha}^{-1}$ of LSM, with an increase of $20 \%$, compared to control treatment. This value is close to the values (56 to $76.7 \mathrm{~g} \mathrm{~kg} \mathrm{ha}^{-1}$ ) obtained by Lima et al. (2016) in Brachiaria hibrida.

Cu concentration ranged from 15.91 to $18.1 \mathrm{mg} \mathrm{kg}^{-1}$ in DM, above the ideal suitable for Urochloa from 4 to $14 \mathrm{mg} \mathrm{kg}^{-1}$ in DM (Raij et al., 1996).

Copper extraction was much lower than that provided via LSM fertilization and, with the exception of iron, microminerals had a residual effect of fertilization, requiring soil monitoring over the years.

LSM has a variable composition in organic and inorganic components. So it is necessary to monitor soil characteristics in order to comply with environmental legislation and prevent soil saturation with undesirable chemical components, protecting the environment (Silva, 2018). The risk to human and animal health is due to the presence of heavy metals such as zinc, copper, chromium, cobalt, manganese and iron in the LSM composition which can be high. 
Table 1. Bromatological production and composition of ruziziensis grass fertilized with liquid swine manure and mineral fertilization.

\begin{tabular}{|c|c|c|c|c|c|c|}
\hline \multirow[b]{2}{*}{ Variables } & \multicolumn{4}{|c|}{ Doses $\left(\mathrm{m}^{3} \mathrm{ha}^{-1}\right)$} & \multirow{2}{*}{$\begin{array}{l}\text { Fertilization } \\
\text { Mineral }\end{array}$} & \multirow[t]{2}{*}{ CV (\%) } \\
\hline & 0 & 100 & 200 & 300 & & \\
\hline $\mathrm{PH}(\mathrm{cm})$ & 52.92 & 53.97 & 56.58 & 60.71 & 66.34 & 3.50 \\
\hline TDMY (kg ha ${ }^{-1}$ ) & 21.545 & 23.420 & 25.622 & $28.151^{*}$ & $31.888^{*}$ & 10.28 \\
\hline $\mathrm{CP}(\%)$ & 5.47 & 6.04 & 6.11 & 6.50 & 8.96 & 3.80 \\
\hline NDF (\%) & 60.92 & 60.98 & 61.15 & 61.26 & 58.20 & 1.80 \\
\hline ADF (\%) & $32.13^{*}$ & $31.37^{*}$ & $31.96 *$ & $32.31 *$ & $31.36^{*}$ & 1.81 \\
\hline
\end{tabular}
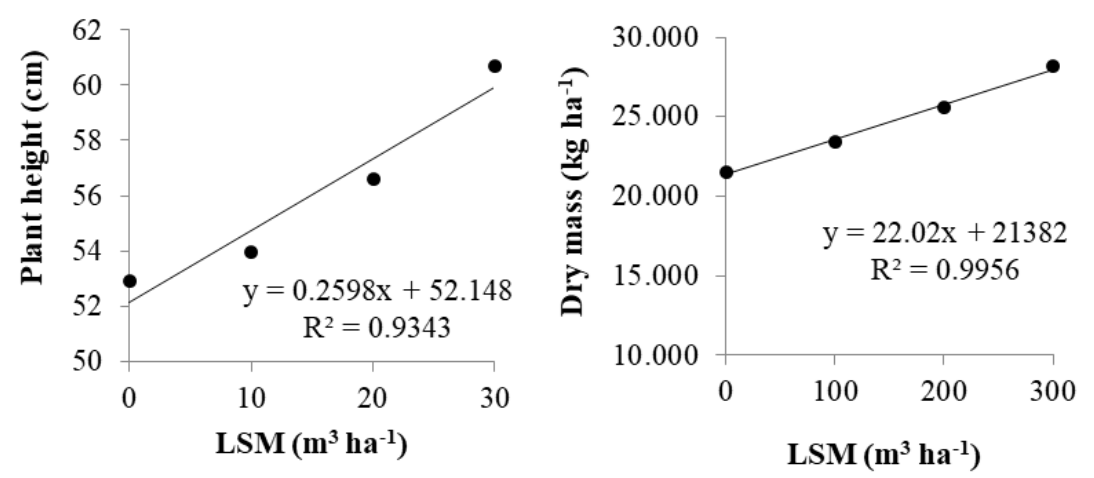

Figure 1. Plant height $(\mathrm{cm})$ average of seven cuts according to the doses of LSM applied by cutting and Total dry mass productivity $\left(\mathrm{kg} \mathrm{ha}^{-1}\right)$ in function on the total volume applied at the end of the cycle.

Table 2. Average extraction by macro and micronutrient cutting by Urochloa ruziziensis grass as a function of LSM doses and mineral fertilization.

\begin{tabular}{|c|c|c|c|c|c|c|}
\hline \multirow[b]{2}{*}{ Variables } & \multicolumn{4}{|c|}{ Doses $\left(\mathrm{m}^{3} \mathrm{ha}^{-1}\right.$ corte $\left.^{-1}\right)$} & \multirow[t]{2}{*}{ Fertilization Mineral } & \multirow[t]{2}{*}{ CV $(\%)$} \\
\hline & 0 & 100 & 200 & 300 & & \\
\hline DMY (kg ha $\left.{ }^{-1}\right)$ & 3077 & 3345 & 3660 & 4021* & $4555^{*}$ & 10.28 \\
\hline$N\left(\mathrm{~kg} \mathrm{ha}^{-1}\right)$ & 27.00 & 32.29 & 35.72 & 41.78 & 65.32 & 12.77 \\
\hline$P\left(\mathrm{~kg} \mathrm{ha}^{-1}\right)$ & 37.01 & 40.49 & 44.98 & $51.93^{*}$ & $63.39 *$ & 12.54 \\
\hline $\mathrm{K}\left(\mathrm{kg} \mathrm{ha}^{-1}\right)$ & 23.10 & 24.98 & 26.79 & $29.59 *$ & $35.11^{*}$ & 15.11 \\
\hline $\mathrm{S}\left(\mathrm{kg} \mathrm{ha}^{-1}\right)$ & 82.07 & 83.77 & 101.04 & 117.05 & 160.79 & 17.57 \\
\hline $\mathrm{Ca}\left(\mathrm{kg} \mathrm{ha}^{-1}\right)$ & 86.71 & 92.31 & 100.04 & $117.05^{*}$ & $128.91^{*}$ & 12.73 \\
\hline $\operatorname{Mg}\left(\mathrm{kg} \mathrm{ha}^{-1}\right)$ & 7.06 & 7.43 & $8.02 *$ & $9.13^{*}$ & $10.17^{*}$ & 14.21 \\
\hline $\mathrm{Fe}\left(\mathrm{g} \mathrm{ha}^{-1}\right)$ & 920 & 956 & $1046^{*}$ & $1199 *$ & $1272^{*}$ & 10.54 \\
\hline $\mathrm{Mn}\left(\mathrm{g} \mathrm{ha}^{-1}\right)$ & 172.92 & 184.39 & 190.89 & $214.54^{*}$ & 241.99* & 10.12 \\
\hline $\mathrm{Zn}\left(\mathrm{g} \mathrm{ha}^{-1}\right)^{\prime}$ & 96.21 & 109.01 & $121.63 *$ & $125.44^{*}$ & $140.49 *$ & 12.65 \\
\hline $\mathrm{Cu}\left(\mathrm{g} \mathrm{ha}^{-1}\right)$ & 54.58 & 58.84 & $65.91 *$ & $63.97^{*}$ & $97.16^{*}$ & 27.36 \\
\hline
\end{tabular}

The means in the lines followed by * do not differ from each other by the Dunnet test $(\mathrm{P}>0.05)$.

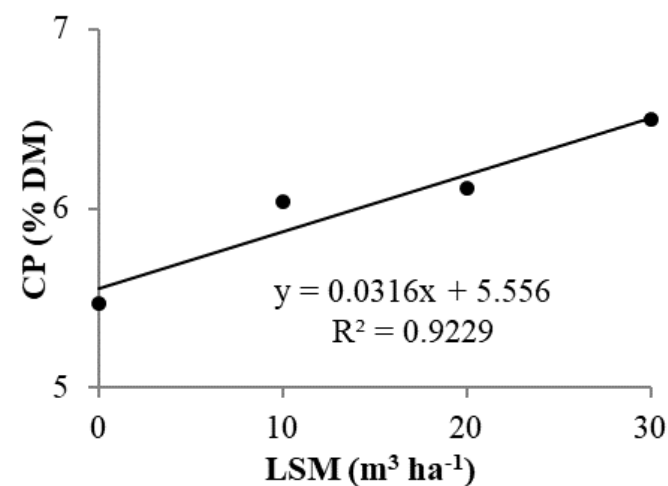

Figure 2. Crude protein content (\%) average of seven cuts according to the LSM doses applied by cut in the forage of Urochloa ruziziensis.

Table 3. Chemical and granulometric characteristics of the soil of the experimental area at a depth of 0 to $0.20 \mathrm{~m}$.

\begin{tabular}{|c|c|c|c|c|c|c|c|c|c|c|c|c|c|c|}
\hline \multicolumn{15}{|c|}{ Chemical and granulometric composition of soil } \\
\hline $\begin{array}{l}\mathrm{pH} \\
\mathrm{CaCl} 2\end{array}$ & $\mathrm{~K}$ & $\mathrm{P}$ & Al & $\mathrm{H}+\mathrm{Al}$ & $\mathrm{Ca}$ & $\mathrm{Mg}$ & SB & CEC & V & $\mathrm{m}$ & $\mathrm{OM}$ & Clay & Silt & Sand \\
\hline & \multicolumn{2}{|c|}{$\mathrm{mg} \mathrm{dm}^{-3}$} & \multicolumn{6}{|c|}{$\mathrm{cmolc} \mathrm{dm}^{-3}$} & \multicolumn{3}{|c|}{$\%$} & \multicolumn{3}{|c|}{$\mathrm{g} \mathrm{kg}^{-1}$} \\
\hline 4.8 & 3.43 & 12.8 & 0.32 & 15.85 & 1.81 & 1.78 & 3.59 & 19.44 & 18.11 & 9.13 & 5.41 & 611 & 20 & 369 \\
\hline
\end{tabular}



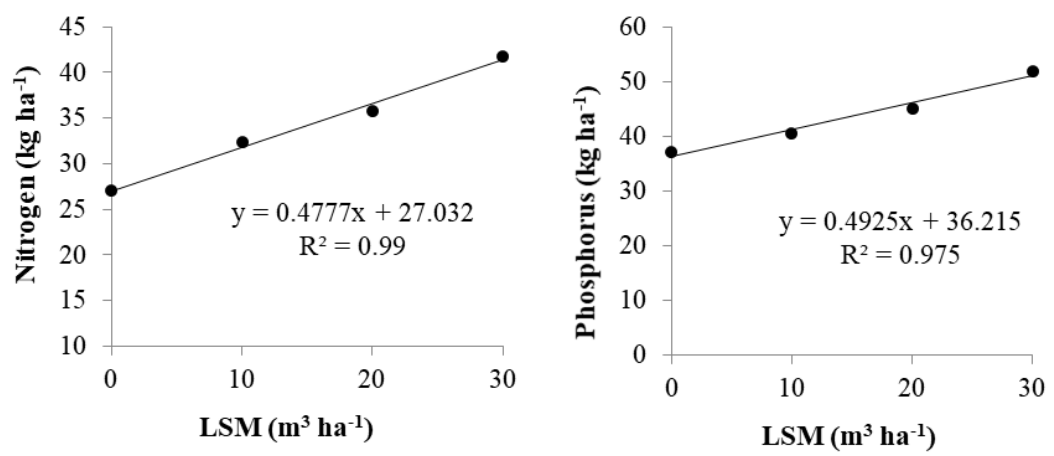

Figure 3. Nitrogen extraction $(\mathrm{N})$ and phosphorus $(\mathrm{P})$, mean values of seven cuts, in function on the LSM doses applied by cut in the forage of Urochloa ruziziensis.

Table 4. Chemical composition $\left(\mathrm{mg} \mathrm{L}^{-1}\right)$ mean of LSM samples applied in experimental plots.

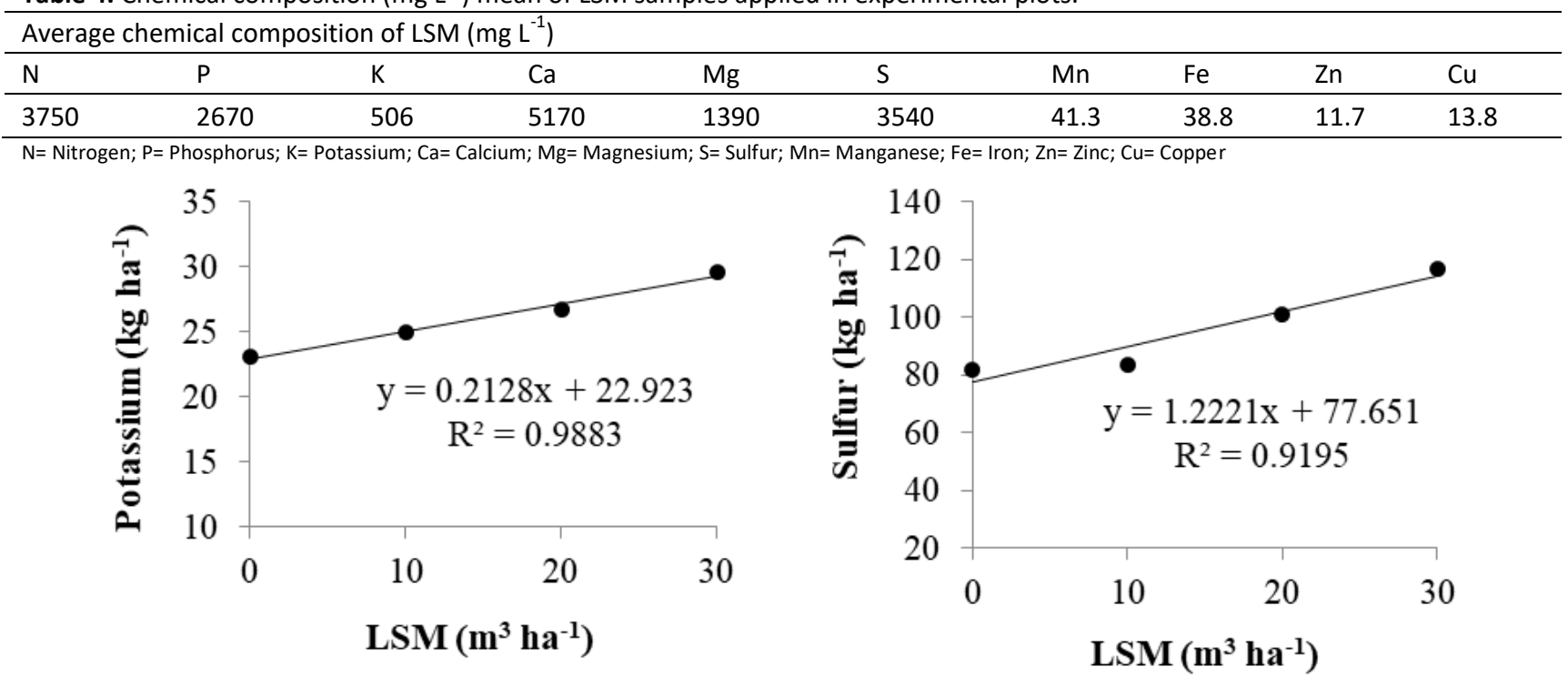

Figure 4. Potassium extraction (K) and sulfur (S), mean values of seven cuts, in function on the LSM doses applied by cut in the forage of Urochloa ruziziensis.

Table 5. Nutrients applied $\left(\mathrm{kg} \mathrm{ha}^{-1}\right)$ via LSM in ten total applications at doses of 100,200 and $300 \mathrm{~m}^{3} \mathrm{ha}^{-1}$.

\begin{tabular}{lllllllllll}
\hline \multicolumn{1}{c}{ Nutrients applied via LSM $\left(\mathrm{kg} \mathrm{ha}^{-1}\right)$} \\
\hline Doses & $\mathrm{N}$ & $\mathrm{K}$ & $\mathrm{P}$ & $\mathrm{Ca}$ & $\mathrm{Mg}$ & $\mathrm{S}$ & $\mathrm{Mn}$ & $\mathrm{Fe}$ & $\mathrm{Zn}$ & $\mathrm{Cu}$ \\
\hline 100 & 375 & 50.6 & 267.5 & 517 & 139 & 354 & 4.13 & 3.88 & 1.17 & 1.38 \\
200 & 745 & 101.2 & 535 & 1034 & 278 & 708 & 8.26 & 7.76 & 2.34 & 2.76 \\
300 & 1125 & 151.9 & 802.5 & 1552 & 417 & 1062 & 12.39 & 11.64 & 3.51 & 4.14 \\
\hline
\end{tabular}
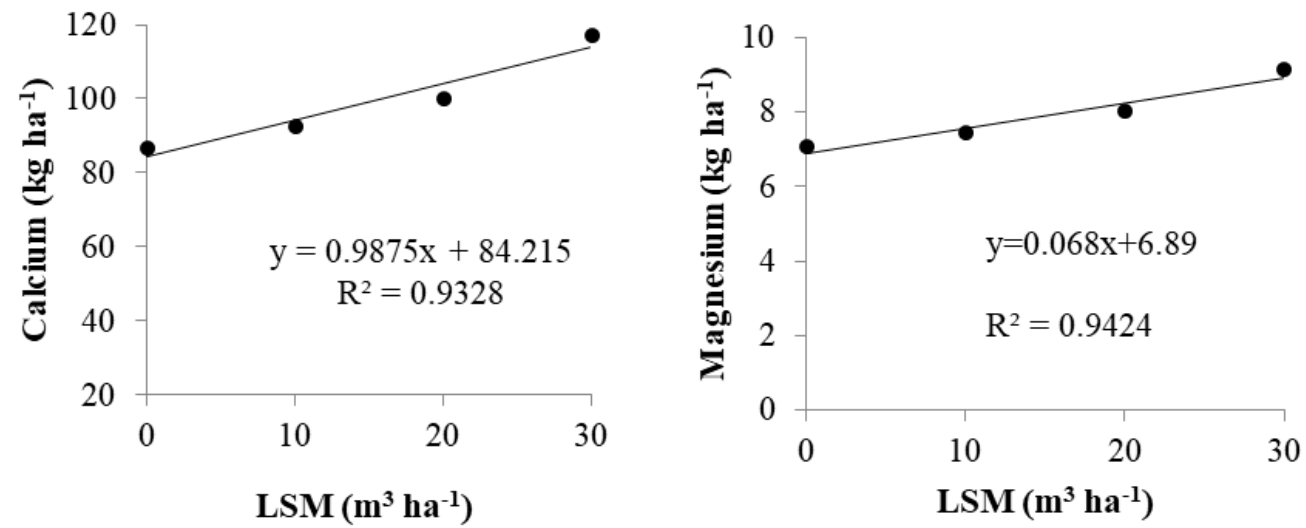

Figure 5. Calcium $(\mathrm{Ca})$ and magnesium extraction $(\mathrm{Mg})$, mean values of seven cuts, in function on the LSM doses applied by cut in the forage of Urochloa ruziziensis. 

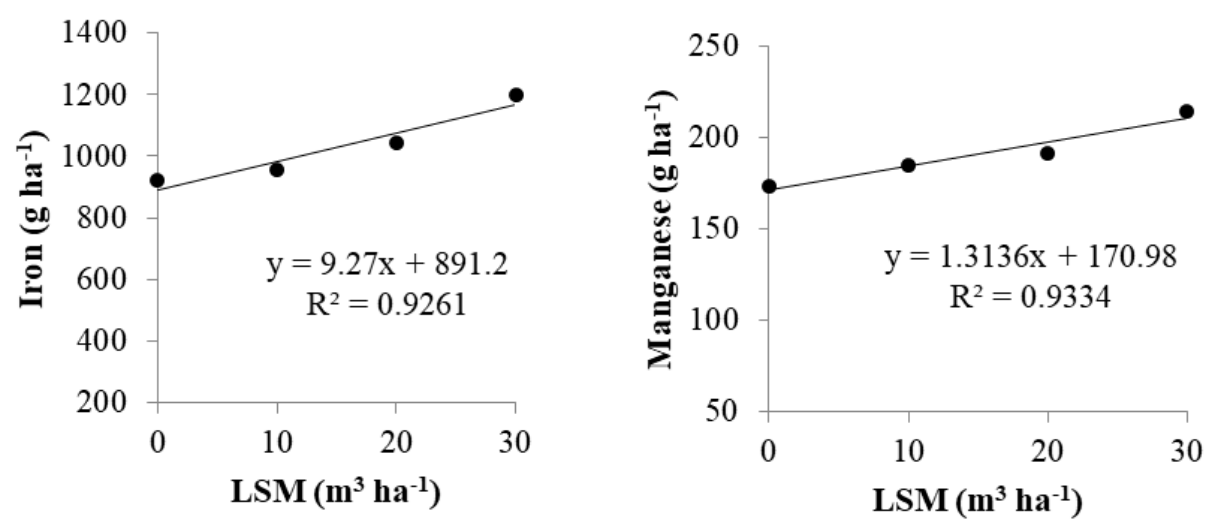

Figure 6. Iron (Fe) and manganese extraction ( $\mathrm{Mn}$ ), mean values of seven cuts, in function on the LSM doses applied by cut in the forage of Urochloa ruziziensis.
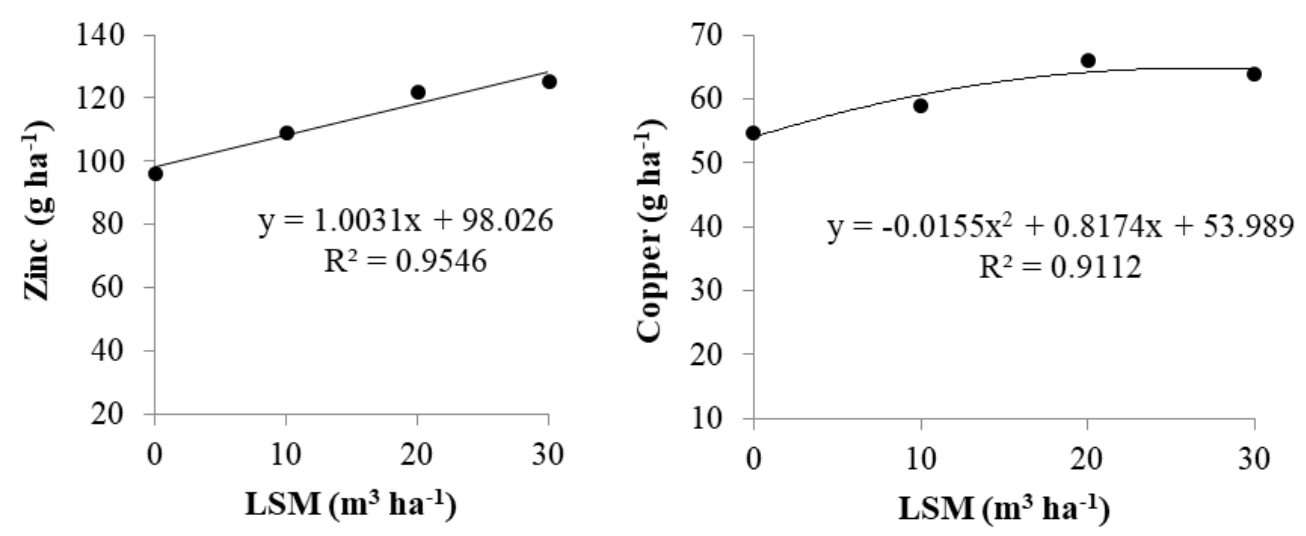

Figure 7. Zinc $(\mathrm{Zn})$ and copper $(\mathrm{Cu})$ extraction, mean values of seven cuts, in function on the LSM doses applied by cut in the forage of Urochloa ruziziensis.

These elements are commonly used as supplements in animal feed to satisfy mineral requirements and improve animal growth performance (Feng et al., 2018).

Changes in the metabolism of plants may occur to increase chance of survival and to develop mechanisms by which excessive amounts of heavy metals can be absorbed and transformed into physiologically tolerable forms (Cobbett, 2000; Hall, 2002). According to the food chain, it is consumed by animals and later by humans, which is why studies on doses to be applied are important.

\section{Materials and methods}

\section{Location of experiment}

The experiment was carried out in the experimental area of the Rio Verde Foundation, located in geographic coordinates $\left(13^{\circ} 00^{\prime} 27^{\prime \prime} \mathrm{S}\right.$ and $\left.55^{\circ} 58^{\prime} 07^{\prime \prime} \mathrm{W}\right)$, with an average altitude of $387 \mathrm{~m}$, in the municipality of Lucas do Rio Verde - MT, Brazil. The climate of the municipality, according to the Classification of Köppen, is type Aw, with an average temperature of $25^{\circ} \mathrm{C}$ and annual precipitation of $2,300 \mathrm{~mm}$.

\section{Soil characterization}

The soil of the experimental area was classified as Dystrophic Oxisol of very clayey texture according to the Brazilian Soil Classification System- SiBCS (Santos, 2018).

The previous crop in the experimental area was soybean that had to be desiccated for the experiment beginning. Soil samples were collected at two depths $(0$ to $0.20 \mathrm{~m})$ for chemical and granulometric characterization (Table 3), according to a methodology recommended by Teixeira et al. (2017).

\section{Experimental design and treatments}

The experimental design was randomized blocks, containing five treatments and four replications. The treatments consisted of four doses of liquid swine manure (LSM) and a mineral fertilization.

The LSM volumes used in the treatments were defined based on the $\mathrm{N}$ content contained in the first analysis that was $5 \mathrm{~g} \mathrm{~L}^{-1}$. Thus, the doses were $0 ; 50 ; 100$ and $150 \mathrm{~kg} \mathrm{ha}^{-1}$ of $\mathrm{N}$. Each experimental unit was $11.0 \mathrm{~m}$ long and $5 \mathrm{~m}$ wide, with spacing between the plots and between the blocks of 5 $\mathrm{m}$. The total volumes applied were: $0 ; 100 ; 200$ and $300 \mathrm{~m}^{3}$ $\mathrm{ha}^{-1}$ of LSM installments in 10 applications, which corresponded to $0 ; 10 ; 20$ and $30 \mathrm{~m}^{3} \mathrm{ha}^{-1}$ per application, respectively.

Mineral fertilization consisted of $40 \mathrm{~kg}$ of $\mathrm{K}_{2} \mathrm{O} ; 70 \mathrm{~kg}$ of $\mathrm{P}_{2} \mathrm{O}_{5}$ and $50 \mathrm{~kg} \mathrm{~N}$ per hectare according to recommendation for Urochloa ruziziensis (Ribeiro et al., 1999).

\section{Source, characterization and preparation of swine manure}

The LSM was processed in a biodigester and was composed of waste (feces, urine, feed residues and water). It was stored in ponds that were open and subject to incidence and variations in rainfall and the dilution effect may have occurred in the doses applied during the conduction of the 
experiment. The doses were fixed in volumes based on the first analysis of the LSM.

Before the application of LSM, samples were collected monthly to analyze its chemical composition. The samples were conditioned and kept under Styrofoam box with ice for macro and micronutrient analysis, heavy metals, according to Table 4.

The doses of LSM were distributed in 10 applications throughout the experiment (March 2014 to January 2015). Table 5 shows the nutrients amount applied in the total volume of LSM during the experimental period. In relation to mineral fertilization, nitrogen was divided into 4 doses of 50 $\mathrm{kg} \mathrm{ha}^{-1}$ of $\mathrm{N}$, totaling $200 \mathrm{~kg} \mathrm{ha}^{-1}$ of $\mathrm{N}$.

\section{Planting and conducting the experiment}

The sowing of Urochloa ruziziensis was performed in January 2014. After 30 days of emergency, uniform cut was performed at $15 \mathrm{~cm}$ of residue height. During the experimental period, seven cuts were made (March, April, May, October, November, December/2014 and January/2015).

There was a resting period of four months (June to September 2014), in which the application of LSM was stopped so that the plant remained nourished because there was a concern with the pasture leafhopper (Deois flavopicta), since the crop is susceptible.

\section{Traits measured}

In each cut, 10 measurements of plant height were performed and three forage samples were collected per plot at residue height of $15 \mathrm{~cm}$, using a square of $0.5 \times 0.5 \mathrm{~m}$ $\left(0.25 \mathrm{~m}^{2}\right)$. The samples of the forage collected were packed in paper bags and identified, weighed to obtain green mass and taken for forced air circulation oven at a temperature of $55^{\circ} \mathrm{C}$ for 72 hours. After that, the plant material was weighed to obtain the dry mass, followed by milling in Willey mill and stored for further laboratory analysis.

In the laboratory analysis of forage, the contents of $\mathrm{N}, \mathrm{P}, \mathrm{K}$, $\mathrm{Ca}, \mathrm{Mg}, \mathrm{S}, \mathrm{Cu}, \mathrm{Fe}, \mathrm{Mn}$, and $\mathrm{Zn}$ were determined according to the methodology described by Malavolta et al. (1997).

The analysis of dry mass productivity and extracted nutrients was performed for each cut and the data were tabled with the means of the seven cuts for each treatment according to the total volume applied.

Crude protein (CP), neutral detergent fiber (NDF) and acid detergent fiber (ADF) were determined according to Silva and Queiroz (2004).

Total dry mass productivity were obtained through forage accumulation in seven cuts, and for the other variables, the means were made by cut.

The data were compiled using the mean values between the cuts for each dose applied $\left(0,10,20,30 \mathrm{~m}^{3} \mathrm{ha}^{-1}\right)$, with the exception of dry mass productivity data that considered the total volume applied $\left(0 ; 100 ; 200\right.$ and $\left.300 \mathrm{~m}^{3} \mathrm{ha}^{-1}\right)$.

\section{Statistical analysis}

The data were subjected to variance analysis. When they were significant, the regression analysis was performed for doses using the statistical program SISVAR (2015) and Dunnett test, to compare the doses of LSM with mineral fertilization, both at $5 \%$ probability using the statistical program SAS.

\section{Conclusion}

Due to the composition of the diets, there is a risk of toxicity by heavy metals when LSM is applied improperly, and therefore it is important that there are studies with different dosages so that the correct dose of LSM is used. The liquid swine manure is an alternative that can replace mineral fertilization for Urochloa ruziziensis grass, especially in regions where there is intensive swine farming. The volume of liquid swine manure of $300 \mathrm{~m}^{3} \mathrm{ha}^{-1}$ promoted dry mass production, without altering the levels of neutral detergent fiber and acid detergent fiber (NDF and ADF), besides improving nutrient concentration in Urochloa ruziziensis available for grazing animals.

\section{Acknowledgments}

To the BRF - Brazil Foods and to the Coordination for the Improvement of Higher Education Personnel (CAPES).

\section{References}

Angers DA, Chantigny MH, Macdonald JD, Rochette $P$, Côté $D$ (2010) Differential retention of carbon, nitrogen and phosphorus in grassland soil profiles with long-term manure application. Nut Cyc in Agroec. 86: 225-229.

Aukar MCM. (2011). Rendimento de sementes de milho, de adubos verdes e de massa de Brachiaria ruziziensis, em cultivo consorciado, em Dourados, MS. UNOESTE, Dourados $68 \mathrm{p}$.

Barnabé MC, Rosa B, Lopes E, Rocha G, Pinheiro E, Freitas $K$ (2007) Produção e composição químico-bromatológica da Brachiaria brizantha cv marandu adubada com dejetos líquidos de suínos. Ciênc Anim Bras. 8: 435-446.

Benett CGS, Buzetti A, Silva KS, Bergamaschine AF, Fabricio JA (2008) Produtividade e composição bromatológica do capim-marandu a fontes e doses de nitrogênio. Ciênc Agrot. 32 (5): 1629-1636.

Bernardi A, Silva AWL, Baretta D (2018) Estudo metanalítico da resposta de gramíneas perenes de verão à adubação nitrogenada. Arq Bras Med Vet Zoot. 70 (2): 545-553.

Boitt G, Schmitt DE, Gatiboni LC, Wakelin AS, Black A, Sacomori W, Condron LM (2018) Fate of phosphorus applied to soil in pig slurry under cropping in southern Brazil. Geod. 321: 164-172.

Brustolin-Golin KD, Scheffer-Basso SM, Escosteguy PAV, Miranda M, Travi MRL, Zabot V (2016) Pig Slurry in Carpet Grass Pasture: Yield and Plant- Available Nitrogen. Rev Bras Eng Agríc Amb. 20: 795-799.

Carvalho MD, Furlani Junior E, Arf O, Sá MD, Paulino HB, Buzetti S (2003) Doses e épocas de aplicação de nitrogênio e teores foliares deste nutriente e de clorofila em feijoeiro. Rev Bras Ciênc Solo. 27 (3): 445-450.

Cassol PC, Cidral CA, Ciprandi O, Pandolfo CM, Ernani PR (2012) Disponibilidade de macronutrientes e rendimento de milho em Latossolo fertilizado com dejeto suíno. Rev Bras Ciênc Solo. 36 (6): 1911-1923.

Castro CS, Lobo UGM, Rodrigues LM, Backes C, Santos AJM (2016) Eficiência de utilização de adubação orgânica em forrageiras tropicais. Rev Agric Neot. 3 (4): 48-54.

Cobbett CS (2000) Phytochelatin biosynthesis and function in heavy metal detoxification. In: Carrington J, Leyser O (ed) Current Opinion in Plant Biology, 1a edn. Elsevier, Parkville 211-216. 
CONAB - Companhia Nacional de Abastecimento (2019) Perspectivas para a agropecuária. Brasília. 7: 1-100

Costa KAP, Oliveira IP, Faquin V, Silva GP, Severiano EC (2009) Produção de massa seca e nutrição nitrogenada de cultivares de Brachiaria brizantha (A. Rich) Stapf sob doses de nitrogênio. Ciênc Agrot. 33: 1578-1585.

Egewarth VA, Egewarth JF, Prior M, Sarto MVM, Kaefer KAC, Moratelli G, Franciscon H, Strenske A, Eckert CT (2015) The effect of swine raising wastewater in the development of millet (Pennisetum glaucum L.), soil and leachate. Afr J Agric Res. 10: 3206-3215.

Eguchi ES, Cecato U, Muniz AS, Da Silva SL, Da Cruz C (2017) Extração de minerais pelo capim marandu fertilizado com esterco de galinha sem e com escarificação. Rev Bras Agrop Sust. 7 (3): 39-47.

Erthal VJT, Ferreira PA, Matos AT, Pereira OG (2010) Alterações físicas e químicas de um argissolo pela aplicação de água residuária de bovinocultura. Rev Bras Eng Agríc Amb. 14: 467-477.

Fagundes JL, Moreira AL, Freitas AWP, Zonta A, Henrichs R, Rocha FC (2012) Produção de forragem de Tifton 85 adubado com nitrogênio e submetido à lotação contínua. Rev Bras Saúde Prod Anim. 13 (2): 306-317.

Feng Z, Zhu H, Deng Q, He Y, Li J, Yin J, Gao F, Huang R, Li T (2018) Environmental pollution induced by heavy metal(loid)s from pig farming. Env Earth Sci. 77: 77-103.

Ferreira DF (2011) Sisvar: A computer statistical analysis system. Ciênc Agrot. 35 (6): 1039-1042.

Galbiatti JA, Silva FG, Franco CF, Caramelo AD (2011) Desenvolvimento do feijoeiro sob o uso de biofertilizante e adubação mineral. Eng Agríc. 31: 167-177.

Galindo FS, Buzetti S, Teixeira Filho MCM, Dupas E, Carvalho FC (2018) Nitrogen management in mombasa guineagrass as a function of sources and rates of nitrogen. Rev Ciênc Agr. 41: 31-40.

Gomes EP, Silva LF, Deboleto JGG, Dias DKU (2014) Produtividade e qualidade do capim piatã sob doses de dejeto suíno líquido tratado na presença e ausência de irrigação. Cad Agroec. 4: 1-10.

Gomes EP, Sanches AC, Deboleto JGG, De Jesus FLF, Mendonça FC (2017) Productivity and nutritional quality of Urochloa brizantha cv BRS piatã grass fertirrigated with swine wastewater in different seasons of the year. Aust J Crop Sci. 11: 1366-1373

Guedes RG (2012) Avaliação do potencial produtivo de gramíneas do gênero Brachiaria nos lavrados Roraimenses. UFRR, Boa Vista 33 p.

Hall JL (2002) Cellular mechanisms for heavy metal detoxification and tolerance. J Exp Bot. 53: 1-11.

Homem BGC, Tavares VB, Almeida Neto OB, Condé MS, Ferreira IM, Silva MD, Lara MAS (2016) Using swine farming wastewater for signal grass cultivation. Ciênc Agr. 37 (4): 2539-2547.

Jones MB, Woodmansee RG (1979) Biogeochemical cycling in annual grassland ecosystems Bot. 45 (2): 111-144.

Kottwitz DC (2012) Resposta de pastagem de grama-tapete no período subsequente à adubação com dejeto líquido de suínos. UPF, Passo Fundo $63 \mathrm{p}$.

Lavoisier AL (1789) Traité élémentaire de chimie. Maxtor France, Paris $362 \mathrm{p}$.

Lima, LC (2016) Bioestimulante e fertilizantes foliares no cultivo de Brachiaria híbrida. UFU, Uberlândia 54 p.
Lourenzi CR, Ceretta CA, Silva LS, Girotto E, Lorensini F, Tiecher TL, De Conti L, Trentin G, Brunetto G (2013) Nutrients in soil layers under no-tillage after successive pig slurry applications. Rev Bras Ciênc Solo. 37: 157-167.

Maggi CF, Freitas PSL, Sampaio SC, Dieter J (2011) Lixiviação de nutrientes em solo cultivado com aplicação de água residuária de suinocultura. Rev Bras Eng Agríc Amb. 15 (2): 170- 177.

Malavolta E, Vitti GC, Oliveira SA (1997) Avaliação do estado nutricional das plantas: princípios e aplicações. 2. ed. Potafos Piracicaba, 319p.

Matos MA, Barbosa GMC, Nogueira MA, Colozzi FA, Andrade DS, Caviglione JH (2017) Chemical and microbiological changes in a sandy soil with pig liquid waste application in southern Brazil. Afri J Agric Res. 11: 5000-5007.

Mendonça VZ, Mello LMM, Andreotti M, Yano ÉH (2014) Teor e acúmulo de nutrientes no consórcio de milho com forrageiras no sistema plantio direto. Rev Bras Ciênc Agr. 9 (3): 330-337.

Lawlor DW, Mengel K, Kirkby EA (2001) Principles of plant nutrition. Annals Bot. 93 (4): 479-480.

Menezes JFS, Berti MPS, Vieira Júnior VD, Ribeiro RL, Berti CLF (2018) Extração e exportação de nitrogênio, fósforo e potássio pelo milho adubado com dejetos de suínos. Rev Agric Neot. 5 (3): 55-59.

Montanari R, Carvalho MDP, Teixeira Filho MCM, Dalchiavon FC (2013) Produção de matéria seca da braquiária de acordo com os atributos químicos de um Latossolo em Selvíria, Mato Grosso do Sul. Rev Ceres. 60 (4): 519-527.

Moraes RE, Silveira RF, Vaniel CR, Pinheiro LJ, Ollé, MA, Silveira, IDB (2017) Suinocultura e o Meio-ambiente. Rev Elect Vet. 18(10): 1-17.

Morales D, Vargas MM, Oliveira MP, Taffe BL, Comin J, Soares CR, Lovato P (2015) Response of soil microbiota to nine-year application of swine manure and urea. Ciênc Rur. 46: 260-266.

Nussio LG, Manzano RP, Pedreira CGS (1998) Valor alimentício em plantas do gênero Cynodon. Paper presented at the simpósio sobre manejo da pastagem, Esalq-USP, Piracicaba.

Orrico Junior MAP, Centurion SR, Orrico ACA, Sunada NS (2012) Effects of biofertilizer rates on the structural, morphogenetic and productive characteristics of Piatã grass. Rev Bras Zoot. 41 (6): 1378-1384.

Orrico Junior MAP, Orrico ACA, Centurion SR, Sunada NS, Lucas Junior J (2013) Valor nutritivo do capim Piatã adubado com diferentes doses de biofertilizante. Agrar. 6 (21): 312-319.

Pandolfo CM, Veiga M (2016) Crop yield and nutrient balance influenced by shoot biomass management and pig slurry application. Rev Bras Eng Agríc Amb. 20: 302-307.

Pariz CM, Andreotti M, Azenha MV, Bergamachine AF, Mello LMM, Lima RC (2010) Massa seca e composição bromatológica de quatro espécies de braquiárias semeadas na linha ou a lanço, em consórcio com milho no sistema plantio direto na palha. Acta Sci Anim Sci, 32: 147154.

Penn CJ, Will R, Fultz L, Hamilton D (2013) Forage and tree seedling growth in a soil with an encased swine sludge layer. J Env Manag. 128: 586-593.

Perondi PAO, Marchesin W, Luz CHP, Herling RV (2007) Guia de identificação de deficiências nutricionais em Brachiaria brizantha cv. Marandu. Embrapa Pecuária, São Carlos 38p. 
Quaresma JPS, Almeida RG, Abreu JG, Cabral LS, Oliveira MA, Carvalho DMG (2011) Produção e composição bromatológica do capim-Tifton 85 (Cynodon spp.) submetido a doses de nitrogênio. Acta Sci Anim Sci. 33 (2): 145-150.

Raij B, Cantarella H, Quaggio JA, Furlani AMC. (1996). Recomendações de adubação e calagem para o Estado de São Paulo. 2.ed. IAC, Campinas 285p.

Ribeiro AC, Guimarães PTG, Alvarez VVH (1999) Recomendação para o uso de corretivos e fertilizantes em Minas Gerais: 5a aproximação. Comissão de Fertilidade do Solo do Estado de Minas Gerais, Viçosa 359 p.

Santos HG, Jacomine PKT, Anjos LHC, Oliveira VA, Lumbreras JF, Coelho MR, Almeida JA, Filho JCA, Oliveira JB, Cunha TJFF (2018) Sistema Brasileiro de Classificação de Solos. 5. ed. Embrapa, Brasília 355p.

Silva MAAPA (2018) Aplicação de água residuária de suinocultura após dois anos sucessivos em sistema agroflorestal. UFU, Uberlândia 64 p.

Silva DJ, Queiroz AC (2004) Análise de Alimentos: métodos químicos e biológicos. UFV, Viçosa $235 \mathrm{p}$.

Silva AC, Freitas FC, Ferreira LR, Freitas RS (2006) Dessecação pré-colheita de soja e Brachiaria brizantha consorciadas com doses reduzidas de graminicida. Pesq Agrop Bras 41: 37-42.

Silva AA, Lana ÂMQ, Lana RMQ, Costa AM (2015) Fertilização com dejetos suínos: influência nas características bromatológicas da Brachiaria decumbens e alterações no solo. Eng Agríc. 35: 254-265.
Silva MR, Abreu JG, Weber OLS, Soares AP, Bonfim-Silva EM, José JV (2019) Marandu, xaraés and piata grasses fertilized with swine wastewater under greenhouse conditions. J Agric Sci. 11 (9): 112-119.

Seidel EP, Gonçalves Junior AC, Vanin JP, Strey L, Schwantes D, Nacke H (2010) Aplicação de dejetos de suínos na cultura do milho cultivado em sistema de plantio direto. Acta Scien. 32: 113-117.

Serafim RS, Galbiatti JA (2012) Efeito da aplicação de água residuária de suinocultura na Brachiaria brizantha cV Marandu. Rev Col Ciênc Anim. 4: 185-203.

Serpa Filho R, Sehnem S, Cericato A, Santos Junior S, Fischer A (2013) Compostagem de dejetos de suínos. Rev Agron Meio Amb. 6: 47-78.

Sousa FA, Campos AT, Silva EB, Gandini AMM, Corrêa JM (2014) Redução do potencial poluidor de dejetos de suínos em lagoas de estabilização em série. Biosc J. 30: 65-73.

Tavanti RFR, Silva FO, Tavanti TR, Lorenzon K, Santos MI, Demicheli M, Costa LC, Montanari R, Breda CC (2017) Crop productivity and soil quality after fertilization with liquid swine manure. Acta Agron. 67 (2): 303-310.

Teixeira PC, Donagema GK, Fontana A, Teixeira WG (2017) Manual de métodos de análise do solo. 3 ed. Embrapa, Brasília 573 p.

Van Soest PJ (1994) Nutritional ecology of the ruminant. 2.ed. Cornell University Press, Ithaca 476p.

Yuan Z, Pan X, Chen T, Liu X, Zhang Y, Jiang S, Sheng H, Zhang $L$ (2018) Evaluating environmental impacts of pig slurry treatment technologies with a life-cycle perspective. J Cleaner Prod. 188: 840-850. 